\title{
MENGELOLA PERUBAHAN: PERENCANAAN KONSERVASI GEDUNG DE JAVASCHE BANK SURABAYA
}

\author{
KWANDA, Timoticin \\ Program Arsitektur, Fakultas Teknik Sipil dan Perencanaan, \\ Universitas Kristen Petra, Surabaya \\ Email: cornelia@petra.ac.id
}

\begin{abstract}
ABSTRAK
Tulisan ini bertujuan untuk memaparkan perubahan atau intervensi yang boleh dilakukan dalam konservasi gedung De Javasche Bank Surabaya agar sesuai dengan prinsip utama konservasi yaitu karakter kejujuran. Untuk itu, permasalahan dalam tulisan ini adalah sejauh mana suatu bangunan pusaka budaya dapat dirubah sebagai akibat dari intervensi yang dilakukan. Mengelola perubahan dalam perencanaan konsevasi gedung ini penting untuk dibahas agar intervensi yang dilakukan tetap memenuhi prinsip konservasi. Metode purposive sampling dipergunakan, yaitu gedung De Javasche Bank Surabaya dipilih menjadi studi kasus karena pada saat itu gedung ini merupakan satu-satunya gedung yang sedang dalam proses perencanaan konservasi di Surabaya. Perencanaan konservasi bangunan tahun 1910 ini merupakan panduan intervensi atau perubahan yang dibuat berdasarkan studi sejarah, dokumentasi bangunan, serta analisis tentang perubahan bangunan, struktur bangunan, dan keaslian material. Hasil studi ini dituangkan dalam intervensi yang dapat dilakukan, seperti pelestarian semua elemen asli bangunan dan sebagian elemen bangunan kondisi eksisting; rehabilitasi, restorasi, dan rekonstruksi elemen bangunan yang telah hilang, rusak, dan belum terungkap termasuk perkuatan struktur bangunan; demolisi elemen tambahan yang menutupi elemen asli; untuk penambahan elemen baru seperti sistim MEP, prinsip intervensi minimum dapat dipenuhi dengan memanfaatkan lubang-lubang yang ada; dan sesuai prinsip 'discernable' dalam konservasi, penambahan elemen arsitektur yang baru dengan material baru sebagai representasi masa kini.
\end{abstract}

Kata kunci: mengelola perubahan, perencanaan konservasi, dan authenticity.

\begin{abstract}
The purpose of this paper is to present changes or interventions that allow to be applied in conservation of De Javasche Bank Surabaya in order to sustain the conservation main principle, authenticity. In this case, the problem of this study is how far a heritage building can be changed as a result of the interventions. Manage change in conservation planning of the building is important to be discussed for the interventions that carried out has to meet the conservation principles. Purposive sampling method is applied, therefore De Javasche Bank Surabaya is selected as the case study because at that time it was the only building that undergoing conservation planning in Surabaya. Conservation planning for the building that built in 1910 is guidance of interventions or changes prepared based on historical study, building documentation, and analysis of the the building transformation, the building structure, and material authenticity. Then, the results of the study was put into the acceptable interventions such as preservation of all the original and some existing elements; rehabilitation, restoration, reconstruction of the broken, ruined, missing elements and the hidden original element, including structure reinforcement; demolition of additional elements that cover the original elements; for the new elements such as MEP, minimum intervention principle can be met by using the existing openings; and to support the discernible principle in conservation, addition of new architecture elements with new materials as representation of the present era.
\end{abstract}

Keywords: Manage change, conservation planning, and authenticity.

\section{PENDAHULUAN}

Pada tahun 1990-an, fenomena 'disappearing Asian city' (Logan 2002), yaitu penghancuran banyak bangunan pusaka budaya di berbagai pusat kota-kota tua di Asia seiring dengan pertumbuhan ekonomi yang pesat, juga terjadi di Indonesia, terutama di Jakarta dan Surabaya. Pada tahun 1995, di Surabaya misalnya, gedung persenjataan yg dibangun pada masa Gubernur Jenderal Daendels (1808-1811) telah dihancurkan dan diganti dengan pertokoan Jembatan Merah Plaza (Dick 2003: 409). Reaksi terhadap fenomena ini adalah munculnya berbagai gerakan masyarakat yang berkampanye untuk konservasi pusaka budaya di berbagai tempat di Asia. ${ }^{1}$ Dampak

\footnotetext{
${ }^{1}$ Seperti pada kasus protes masyarakat terhadap pembangunan hotel baru Golden Hanoi tahun 1996 di kawasan Sino-Vietnam dan kolonial Perancis, Hanoi (Logan 2002); pada tahun 2000 di Hong Kong protes masyarakat untuk memasukan desa nelayan terakhir
} 
dari berbagai gerakan pelestarian ini adalah terdapat upaya-upaya konservasi di Asia, seperti yang terekam dalam Asia Conserved (Engelhardt \& Unakul eds. 2007).

Di Indonesia, beberapa bangunan yang telah dikonservasi dan mendapat penghargaan UNESCO Asia-Pacific Heritage Award yaitu pada tahun 2001 untuk Gedung Arsip Nasional di Jakarta. Gedung lain yang telah melakukan upaya konservasi adalah gedung De Javasche Bank di Jakarta yang telah difungsikan untuk museum uang di tahun 2009. Selain itu, Bank Indonesia juga telah melakukan upaya konservasi dengan menyusun perencanaan konservasi untuk gedung De Javasche Bank di Surabaya. Perencanaan konservasi suatu bangunan pusaka budaya disusun harus memperhatikan prinsipprinsip konservasi yang berlaku dalam dunia konservasi, dan telah berkembang sejak abad 19 yang tertuang dalam beberapa piagam yang berlaku secara nasional maupun internasional, seperti pembahasan berikut ini.

\section{Prinsip Konservasi dan Mengelola Perubahan}

Perencanaan konservasi gedung ini bertujuan untuk menyusun pedoman konservasi untuk memastikan intervensi atau perubahan yang akan dilakukan dapat memenuhi prinsip utama konservasi yaitu prinsip keaslian atau karakter jujur (authenticity). Untuk melaksanakan prinsip utama ini, maka upaya konservasi harus memperhatikan prinsip lainnya, yaitu (1) prinsip intervensi minimum (minimum intervention) yang menjadi prinsip dalam praktek konservasi di dunia dimulai oleh the Society for the Preservation of Ancient Buildings Manifesto di tahun 1877; (2) prinsip reversible, yaitu intervensi yang telah dilakukan di kemudian hari dapat dikembalikan ke kondisi semula; (3) prinsip recognizable as a new yaitu bahan baru (replika) dan teknik baru harus dipergunakan agar dapat membedakan antara elemen yang baru dengan yang lama, seperti tercantum dalam piagam: Athens Charter 1931, Venice 1964, dan Burra Charter 1999. Pada kasus candi Boroburur misalnya, material baru berupa batu replika diberi tanda berupa pin timah, dan pada kasus rekonstruksi Bangsal Trajumas di Kraton Yogyakarta replika kayu diberi tanda dengan pin kuningan (Gambar 1).

Tai O sebagai kawasan pusaka budaya (Chu 2007). Di Indonesia, munculnya gerakan-gerakan pelestari pusaka budaya melalui organisasi seperti Bandung Heritage Society (didirikan tahun 1987), Bali Heritage Trust (2000), Yogyakarta Heritage Society (1991), Sumatera Heritage (1998), West Sumatra Heritage (1999), Surabaya Heritage (2007), Ternate Heritage Society (2008), dan pada tingkatan nasional BPPI (2004).
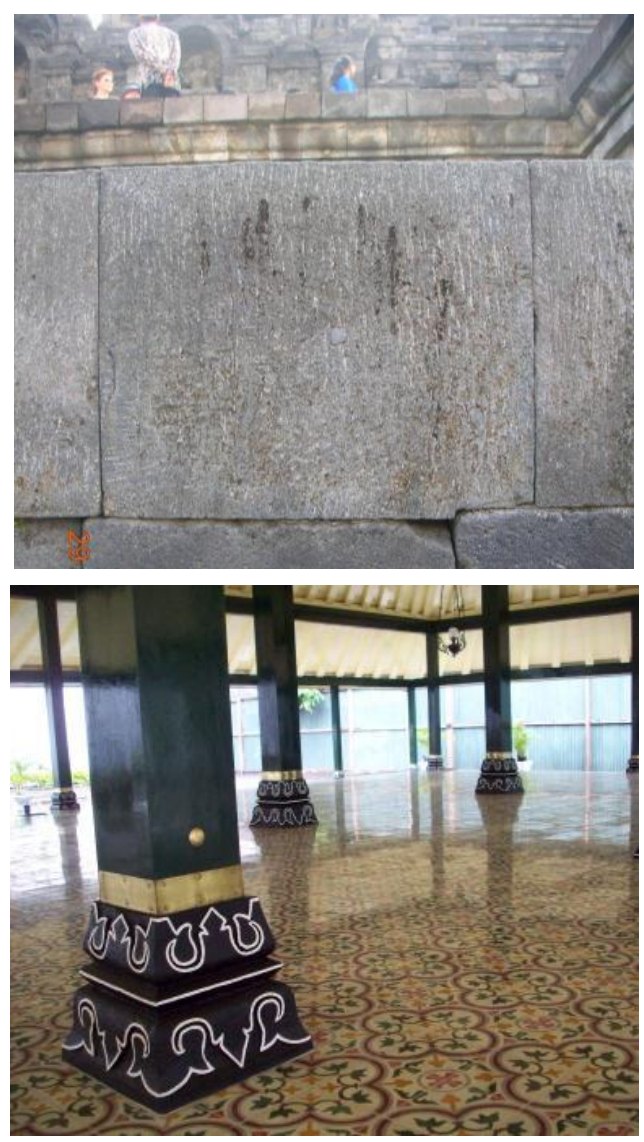

Gambar 1. Pemberian tanda untuk membedakan elemen asli dengan replika pada batu Candi Borobudur, dan soko guru Bangsal Trajumas, Kraton Yogyakarta

Pada satu sisi, prinsip-prinsip konservasi ini harus dipenuhi dalam konservasi, pada sisi lain suatu bangunan telah mengalami banyak perubahan sepanjang masa perjalanannya yang dimulai pada saat pertama kali dibangun (original state), sampai pada kondisi saat ini (existing state), sehingga ketika intervensi perlu dilakukan, interventi seperti apa dan pada periode apa - periode original state, existing state dan diantara kedua perode tersebut- yang akan yang akan diambil dengan tetap dapat memenuhi prinsip konservasi. Membuat keputusan intervensi seperti apa dan periode apa tentang usulan-usulan perubahan pada bangunan inilah yang dimaksud dengan mengelola perubahan.

Secara teoritis, mengelola perubahan dalam konservasi telah berkembang dari pandangan abad ke-19 yang hanya berpusat pada objek atau bangunan, ekspresi artistik yang monumental, ke pandangan yang berpusat pada subjeknya yaitu masyarakat. Pada tahun 1877, istilah 'conserved as found' menjadi prinsip utama untuk menjaga integritas estetika dan keaslian bahan yang dipelopori oleh the Society for the Preservation of Ancient Buildings (SPAB), dengan tokoh utamanya William Morris. 
Pada akhir tahun 1990-an, konservasi masih tetap berfokus pada objek yaitu tentang proses memelihara bangunan yang disebut dalam beberapa piagam, dokumen dan literatur seperti (table 1). Misalnya dalam buku Feilden (1982) edisi yang pertama, koservasi diartikan sebagai 'the action taken to prevent decay', dan pada Piagam Burra butir 1.4 (1999), konservasi diartikan sebagai 'all the process of looking after a place so as to retain its cultural significance'. Kata 'manage change' tidak disinggung dalam beberapa piagam dan literatur di atas, hal ini merupakan refleksi dari pandangan bahwa pusaka budaya terisolasi dari perubahan yang dinamis dalam masyarakat.

Namun dalam perjalanan waktu, terjadi perubahan pemahaman dari perhatian ke objek menjadi ke subjek, kata 'manage change' mulai disinggung dalam buku Feilden (2003) yang terakhir, konservasi didifinisikan sebagai suatu kegiatan untuk mencegah kerusakan suatu bangunan dan mengelola perubahan yang telah dan akan terjadi pada bangunan yaitu 'the action taken to prevent decay and manage change dynamically', dan mengelola perubahan diartikan sebagai membuat keputusan konservasi yang optimum mengenai usulan perubahan pada bentuk, material, teknik, seperti tercantum di bawah ini:

Managing change is about making the optimum conservation decision of proposed changes in case of form, materials, construction techniques, and usage of a building, based on careful assessment of the relative importance of each value.

Table 1. Perubahan Definisi Konservasi dari Waktu ke Waktu

\begin{tabular}{|c|c|c|c|}
\hline Tahun & $\begin{array}{c}\text { Piagam/Pakar/ } \\
\text { Institusi }\end{array}$ & Aktivitas & Tujuan \\
\hline 1964 & Venice & $\begin{array}{l}\text { Tidak ada } \\
\text { definisi }\end{array}$ & $\begin{array}{l}\text { Work of art as } \\
\text { historical } \\
\text { evidence (artikel } \\
\text { 3) }\end{array}$ \\
\hline 1988 & Burra & $\begin{array}{l}\text { all the process } \\
\text { of looking after } \\
\text { a place (artikel } \\
\text { 1.4) }\end{array}$ & $\begin{array}{l}\text { to retain its } \\
\text { cultural } \\
\text { significance } \\
\text { (artikel 2) }\end{array}$ \\
\hline $\begin{array}{l}1982, \\
1989\end{array}$ & Feilden (hal. 3) & $\begin{array}{l}\text { the action } \\
\text { taken }\end{array}$ & to prevent decay \\
\hline 2003 & Feilden (hal. 3) & $\begin{array}{l}\text { the action } \\
\text { taken; and } \\
\text { manage change } \\
\text { dynamically }\end{array}$ & to prevent decay \\
\hline 2008 & $\begin{array}{l}\text { English Heritage } \\
\text { Principles (hal. } \\
\text { 22) }\end{array}$ & $\begin{array}{l}\text { process of } \\
\text { managing } \\
\text { change }\end{array}$ & $\begin{array}{l}\text { to sustain the } \\
\text { values }\end{array}$ \\
\hline
\end{tabular}

Demikian juga dalam dokumen the English Heritage (2008), konservasi telah didifinisikan sebagai suatu proses mengelola perubahan yaitu 'the process of managing change in ways that will best sustain the values of a place in its contexts, and which recognises opportunities to reveal and reinforce those values'.

Untuk itu, mengelola perubahan suatu bangunan dalam perencanaan konsevasi gedung De Javasche Bank ini sangat penting untuk dibahas agar intervensiinterventi yang akan dilakukan pada bangunan dan akan merubah bangunan pusaka budaya ini tetap dapat memenuhi prinsip utama konservasi.

\section{Tujuan dan Rumusan Masalah}

Dalam hal mengelola perubahan, tulisan ini bertujuan untuk memaparkan perubahan atau intervensi yang dapat dilakukan dalam perencanaan konservasi gedung De Javasche Bank Surabaya sehingga sesuai dengan prinsip konservasi yang berlaku. Perencanaa konservasi ini bertujuan untuk memastikan bahwa semua intervensi-intervensi yang akan dilakukan dapat memenuhi prinsip-prinsip konservasi, seperti keaslian atau karakter kejujuran (authenticity) dan lainnya. Untuk itu, permasalahan dalam tulisan ini adalah sejauh mana suatu bangunan pusaka budaya dapat dirubah sebagai akibat dari intervensi-intervensi yang akan dilakukan dalam rangka konservasi bangunan De Javsche Bank Surabaya ini.

\section{METODE PENELITIAN}

Metode puposive sampling merupakan metode penelitian yang dipergunakan untuk studi ini. Dalam hal ini, gedung De Javasche Bank Surabaya secara sengaja menjadi pilihan kasus studi dengan pertimbangan bahwa pada saat penelitian ini akan dimulai gedung ini merupakan satu-satunya gedung yang sedang dalam proses perencanaan konservasi di Surabaya. Pengumpulan data untuk perencanaan konservasi ini disusun berdasarkan beberapa metode, seperti (1) studi kepustakaan yang berhubungan dengan dokumen, foto dan Gambar tentang perancangan bangunan, material bangunan, dan elemenelemen arsitektur bangunan ini, (2) wawancara dengan para nara sumber, (3) studi lapangan untuk membandingkan data kepustakaan dengan kondisi fisik di lapangan untuk memastikan keaslian elemenelemen arsitektur bangunan.

Untuk mengetahui keaslian elemen-elemen arsitektur dan material bangunan dilakukan tiga metode yaitu (1) metode ilmiah yaitu melalui uji laboratorium 
yang dapat dilakukan di Balai Besar Konservasi Peninggalan Borobudur di Magelang, misalnya untuk mengetahui komposisi asli material plaster dinding; (2) eskavasi arkeologis, dimaksudkan untuk mengetahui tinggalan arkeologis, baik struktural atau artefak; dan (3) analisis tipologi bentuk dan bahan bangunan yaitu membandingkan bangunan yang diteliti dengan bangunan yang memiliki karakter yang relatif sama seperti bangunan dirancang oleh biro arsitek yang sama, fungsi bangunan yang sama, dan tahun pembangunan yang sama.

\section{HASIL DAN PEMBAHASAN}

\section{Perencanaan Konservasi}

Perencanaan konservasi De Javasche Bank Surabaya disusun melalui beberapa studi yaitu studi sejarah bangunan, dan dokumentasi bangunan, sebagai berikut:

\section{Studi Sejarah}

\section{A. Kelahiran De Javasche Bank Surabaya}

Pada tanggal 24 Januari 1828, dengan surat keputusan komisaris Jendral Hindia Belanda no. 25, ditetapkan pendirian De Javasche Bank, dengan kantor pusat didirikan di Batavia, dan membuka cabang diberbagai kota, seperti kantor cabang $D e$ Javasche Bank Surabaya dibuka pada tanggal 14 September 1829 (Gambar 2). Pada tahun 1910, gedung tahun 1829 ini dirobohkan dan diganti dengan gedung baru di lokasi yang sama dengan gaya arsitektur Neo Renaissance atau gaya Eklektisisme. Perancangan gedung baru ini dilakukan oleh biro arsitek terkemuka di Hindia Belanda bernama N.V. Architecten-ingenieursbureau Hulswit en Fermont te Weltevreden en Ed. Cuypers te Amsterdam yang didirikan pada tahun 1910 oleh Eduard Cuypers (1859-1927) dan Marius J. Hulswit, bersama A.A. Fermont. Sampai tahun 1942, De Javasche Bank Surabaya masih dikuasai oleh Belanda, dan setelah pendudukan tentara Jepang yang singkat sampai tahun 1945, bank ini tidak lagi beroperasi. Namun setelah tentara sekutu menduduki Surabaya, De Javasche Bank dapat beroperasi kembali pada tanggal 6 April 1946. Pada tanggal 1 Juli 1953 Bank ini berubah menjadi Bank Indonesia dengan menempati kantor yang sama, baru pada tahun 1973 menempati gedung baru di Jl. Pahlawan 105, Surabaya.

\section{B. Perubahan Bangunan}

Studi perubahan pada fisik bangunan ini bermanfaat untuk mencari kondisi asli bangunan pada periode 'original state' yaitu ketika bangunan pertama kali selesai dibangun, dan 'existing state' yaitu kondisi bangunan pada saat ini. Kondisi 'original state' diperlukan agar intervensi yang dilakukan pada bangunan sesuai dengan prinsip utama konservasi, authenticity, yaitu kondisi asli yang sejujurnya. Studi dokumen sejarah bangunan De Javasche Bank Surabaya menjelaskan secara umum peristiwa dan perubahan yang penting pada bangunan yaitu (a) pada tahun 1910 bangunan pertama yang dibanguntahun 1829 diganti dengan bangunan baru; (b) selama periode tahun 1910-1922, bangunan ini tidak banyak mengalami perubahan yaitu hanya ada penambahan talang menurun di atap (Gambar 2) ${ }^{2}$; (c) selama periode tahun 1922-1942, dan selama periode tahun 1946-1973 yaitu pada saat Bank Indonesia Surabaya menempati bangunan baru di Jalan Pahlawan, kemungkinan terjadi perubahan seperti pintu masuk utama pindah ke tengah bangunan, penambahan bangunan baru di sisi Timur berfungsi untuk ruang direksi, dan penambahan bangunan baru di sisi Selatan dengan konstruksi baja.

\section{Dokumentasi Bangunan}

Dokumentasi dilaksanakan melalui studi dokumen sejarah (foto, naskah tulisan) dan survei banguan di lokasi untuk mengumpulan data tentang kondisi fisik bangunan yang meliputi perubahan dan kondisi setiap elemen arsitektur dan struktur bangunan, seperti pada Gambar 2.

\section{A. Kondisi Arsitektur Bangunan}

Dokumentasi arsitektur bangunan meliputi semua elemen bangunan baik yang masih asli sejak bangunan didirikan ataupun dihilangkan karena elemen tambahan hasil renovasi terdahulu. Bagian bangunan yang telah mengalami kerusakan antara lain (Gambar 2 dan 3) $)^{3}$ : (a) lantai tegel berukuran 150 x 150 mm mengalami kerusakan, hilang, dan kondisi pecah; (b) sebagian kaca jendela yang pecah, dan tertutup oleh triplek, sedangkan kondisi cat pada kusen jendela sudah terkelupas dan kusam. Kondisi pintu banyak yang sudah rusak, berkarat dan macet; (c) pintu utama bangunan tahun 1910 yang terletak di sisi kiri bangunan, kini telah bergeser letaknya ke tengah bangunan denga penambahan kanopi fiber dan

\footnotetext{
2 Berdasarkan perbandingan antara dokumen seperti foto bersumber dari buku, jurnal, koleksi Bank Indonesia dan KITLV dengan hasil dokumentasi saat ini.

${ }^{3}$ Tidak semua hasil dokumentasi masuk dalam tulisan ini karena ketentuan batasan jumlah halaman untuk jurnal ini, untuk hasil dokumentasi yang lengkap dapat dilihat pada buku Kwanda, T. et al (2010).
} 


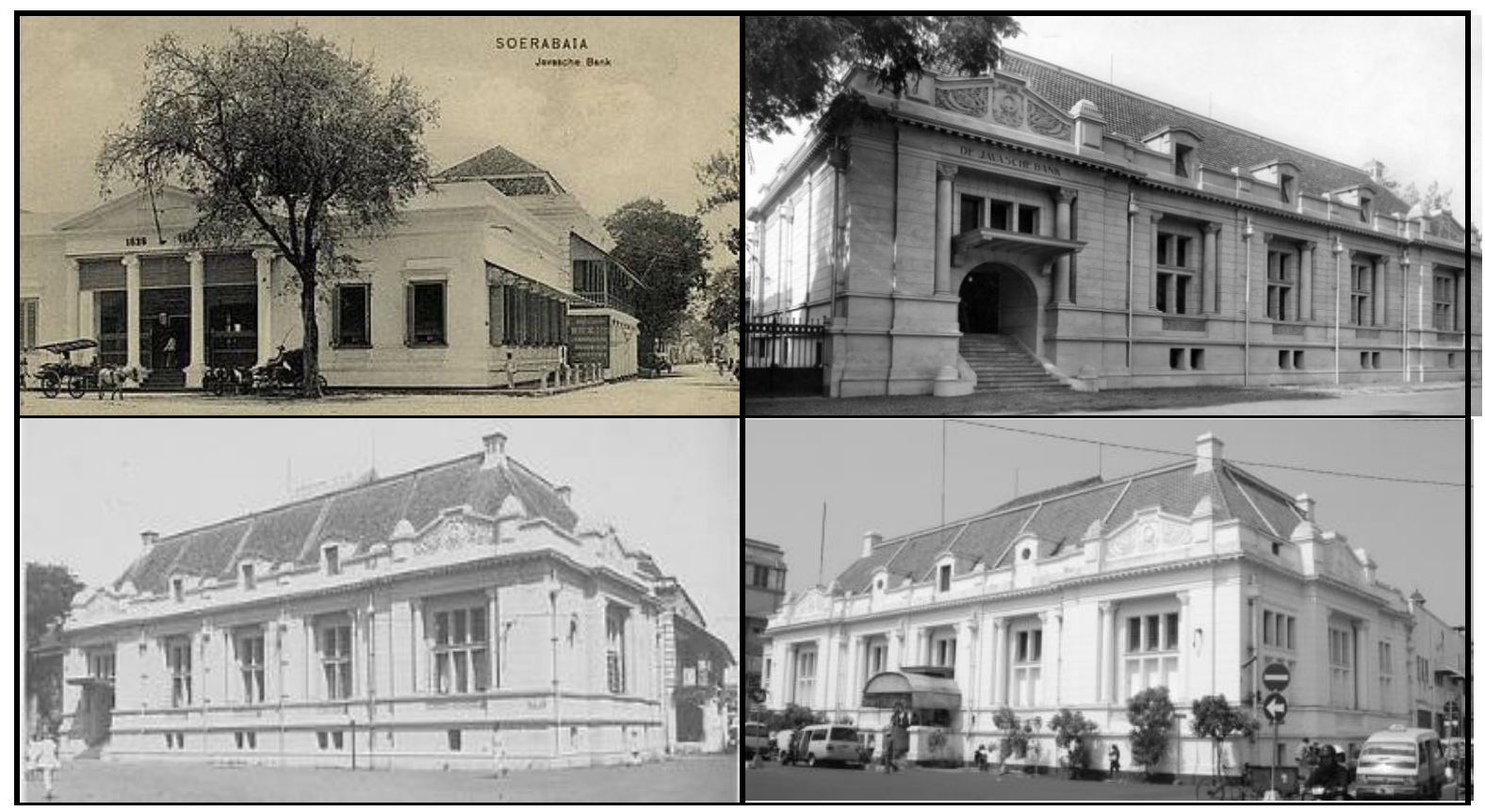

Gambar 2. Foto bangunan tahun 1829 (kiri atas), tahun c. 1915 (kanan atas), tahun 1922 (kiri bawah), dan tahun 2009 (kanan bawah). Sumber: KITLV (foto 1828, c.1915 dan 1922).

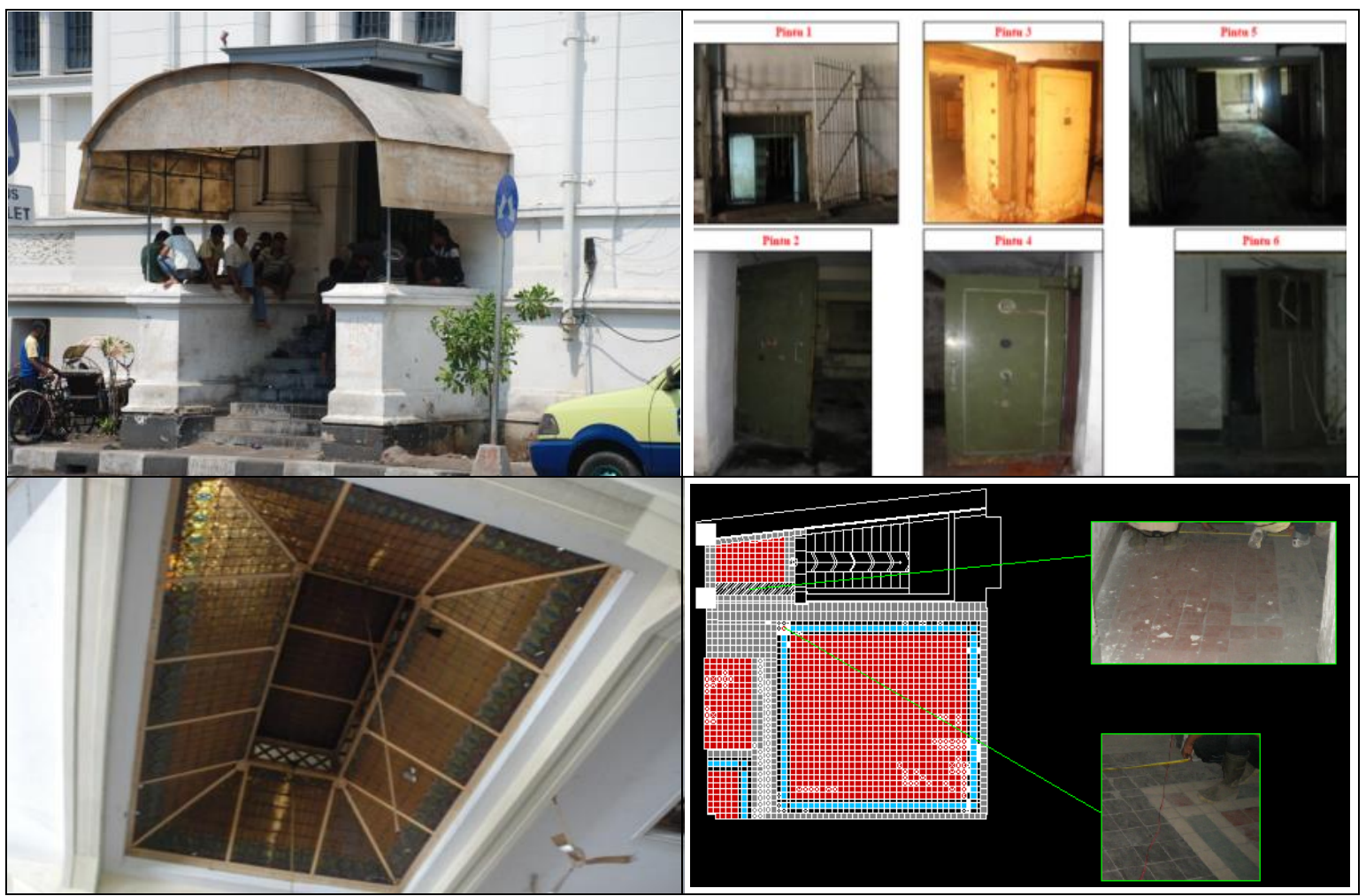

Gambar 3. Kondisi eksterior bangunan dengan penambahan kanopi (kiri atas) dan kondisi pintu kasanah lantai dasar (kanan atas), kondisi skylight kaca patri (kiri bawah), kondisi tegel pada zona B-3 lantai 1 (kanan bawah)

penggantian keramik pada tangga masuk, dan pintu putar dari baja kondisi telah berkarat dan tidak dapat berfungsi; (d) penambahan exhaust fan pada domer window menyebabkan perubahan pada tampak bangunan, yaitu Domer Window berbentuk segiempat menjadi berbentuk lingkaran; (e) skylight dengan kaca berwarna terletak ditengah-tengah ruangan pada bangunan dalam keadaan tidak terawatt, 
kusam dan ada beberapa yang pecah; (f) ornamen pada kolom telah hilang disebabkan oleh pengecatan kembali pada bangunan.

\section{B. Kondisi Struktur Bangunan}

Survei struktur bangunan dilakukan berdasarkan pengamatan forensik yang dilakukan pada bangunan dengan pengamatan visual, serta pengamatan Non Destructive Testing. Hasil studi struktur bangunan menunjukan terjadi kerusakan pada struktur bangunan, seperti kerusakan pada bagian struktur lantai dasar karena terendam air dalam waktu yang lama. Struktur yang mengandung tulangan besi mengalami proses korosi, sehingga terjadi pembesaran volume karat mencapai hingga enam kali lipat dari kondisi semula (Gambar 4). Hal tersebut akan menyebabkan retak pada beton atau plesteran, dan menyebabkan spalling atau lepasnya selimut beton. Struktur bangunan utama dan tambahan merupakan bangunan tua yang belum memperhitungkan faktor pembebanan gempa pada saat pembangunannya, sehingga perlu analisa menyeluruh terhadap struktur penahan beban gempa dengan mempertimbangkan beban peruntukan bangunan.

\section{Pembuatan Gambar}

Untuk pembuatan gambar bangunan, metode yang digunakan meliputi whole model photo yaitu dokumentasi dengan foto pada setiap sisi bangunan yang ada, data arsitektural, tapak bangunan dan elemen-elemen arsitektural; dan alignment dan digital helper data untuk proses pengukuran di lapangan (Gambar 5). Selain tiu, karena bangunan tidak memiliki arsip gambar teknis, untuk itu dilakukan pengukuran sesuai kondisi terakhir bangunan, meliputi pembuatan area pengukuran dengan menggunakan sistem grid untuk mempermudah dan mempercepat pengerjaan pengukuran lapangan; membuat sketsa area yang akan diukur; proses pengukuran manual eksterior dan interior bangunan, serta proses verifikasi data dengan bantuan alat ukur laser (Gambar 5).

Tahap penggambaran merupakan hasil dokumentasi foto dan pengukuran lapangan dengan membuat elemen arsitektur 3D sebagai media informasi melalui proses BIM (Building Information Modeling). Proses pembuatan model bangunan ini meliputi data alignment sebagai basis Gambar dan dilanjukan dengan verifikasi lapangan (Gambar 5).

\section{Pedoman Konservasi}

Berdasarkan pertimbangan studi sejarah, dokumentasi arsitektur dan struktur bangunan, maka dapat disusun pedoman konservasi dengan intervensiintervensi seperti:

a) Mempertahankan (to retain/to preserve) semaksimal mungkin bentuk, bahan, dan teknologi bangunan tahun 1910, dan elemen-elemen arsitektur dalam sepanjang perjalanan sejarah bangunan.
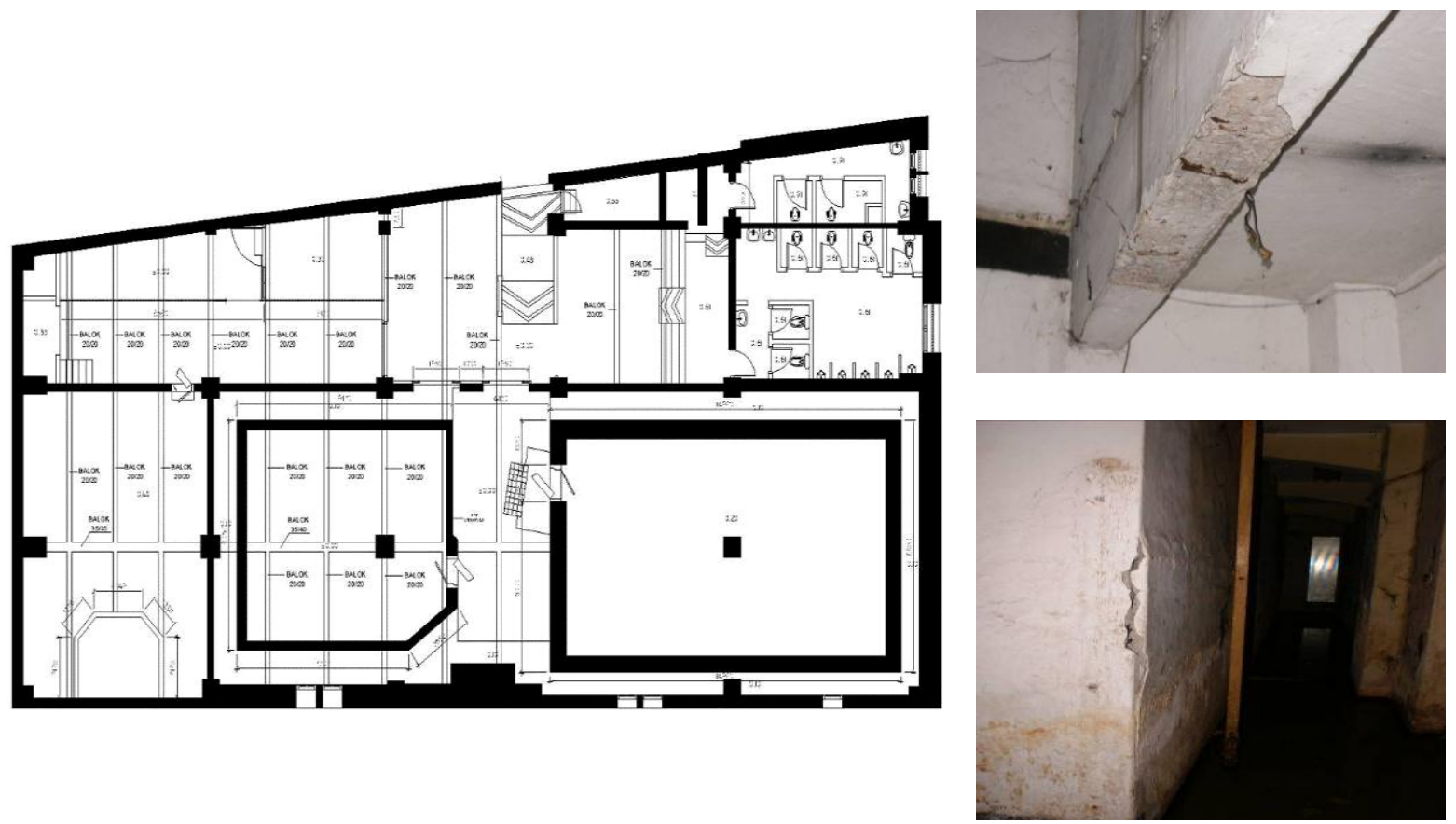

Gambar 4. Pemetaan titik kerusakan struktur lantai dasar (kiri), dan contoh kerusakan pada dinding kazanah dan balok lantai 1 (kanan atas dan bawah) 


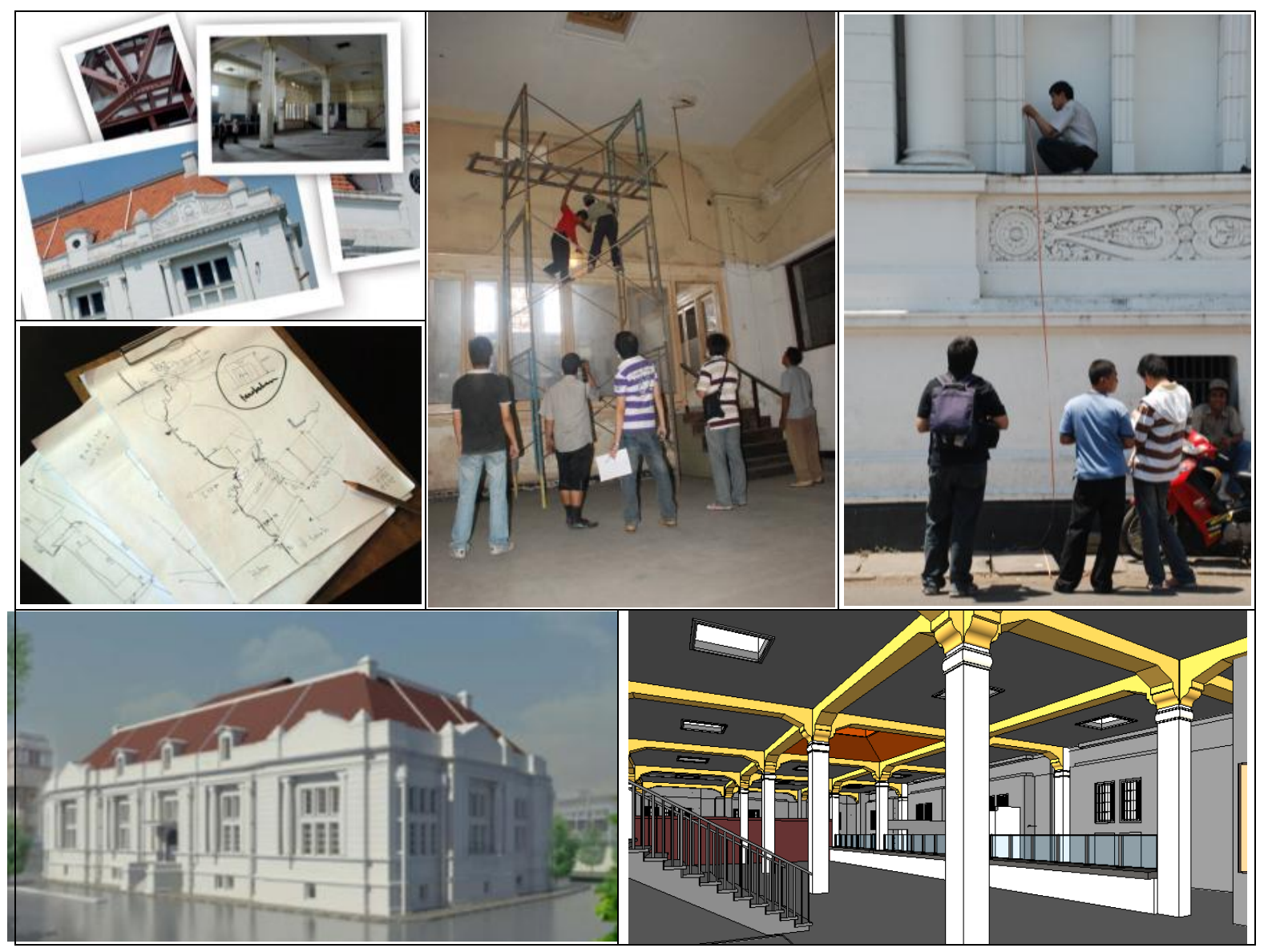

Gambar 5. Pembuatan foto, sketsa gambar dan pengukuran bangunan di lapangan (atas), dan hasil pembuatan 3 D model bangunan kondisi eksisting eksterior dan interior (bawah)

Pinsip ini sesuai dengan prinsip konservasi dalam praktek di dunia internasional seperti prinsip 'material authenticity' (SPAB, Athens Charter 1931, dan Venice Charter 1964), atau prinsip 'the original state' (Burra Charter 1999).

b) Mengembalikan (to reinstate/restore) elemenelemen arsitektur bangunan tahun 1910 yang telah hilang atau rusak dengan cara rekonstruksi disebut juga sebagai anastylosis (Athens Charter 1931) dengan pendekatan ilmiah seperti studi tipologi dan uji laboratorium.

c) Menampilkan kembali (to reveal) bangunan ke kondisi tahun 1910 dengan menghilangkan dan atau membersihkan elemen arsitektur yang menutupi kondisi bangunan tahun 1910.

Penyusunan Pedoman Konservasi ini bertujuan untuk memberikan arahan konservasi untuk mempertahankan dan mengembalikan kondisi bangunan pada periode tahun 1910 dengan nilai-nilai historis dan estetikanya, seperti yang tertulis dalam Piagam Venice, artikel 9, bahwa, 'Its aim is to preserve and reveal the aesthetic and historic value of the monument and is based on respect for original material and authentic documents'. Secara rinci tujuan konservasi ini adalah sebagai berikut:

\section{A. Pedoman Intervensi Arsitektur}

Pedoman konservasi untuk bangunan ini antara lain adalah pada tampak utara bangunan, pedoman konservasi adalah (Gambar 6): (1) mempertahankan tampak bangunan saat ini termasuk semua elemen arsitektur, seperti: (a) pintu masuk utama, tangga dan kanopi, jendela dan pilaster, jendela domer, talang air hujan yang ada; (b) ukiran pada parapet, cornice dan dentil, dan teralis besi pengaman pada semua jendela; (2) menghilangkan: (a) penutup jendela dari papan tripleks; (b) penutup fiber-glass tambahan pada pintu masuk; (3) mengembalikan: (a) tampilan kusen dan daun jendela dari lapisan cat menjadi lapisan pelitur; (b) 2 jendela domer ke bentuk semula yaitu ke bentuk empat persegi; (c) tulisan Javasche Bank pada parapet bangunan dengan menhilangkan cat/unsur yang menutup tulisan tersebut. Pada Tampak Barat (1) mempertahankan tampak bangunan yang ada saat ini, termasuk: (a) jendela dan pilaster, teralis besi pengaman pada semua jendela, talang air hujan; (b) 


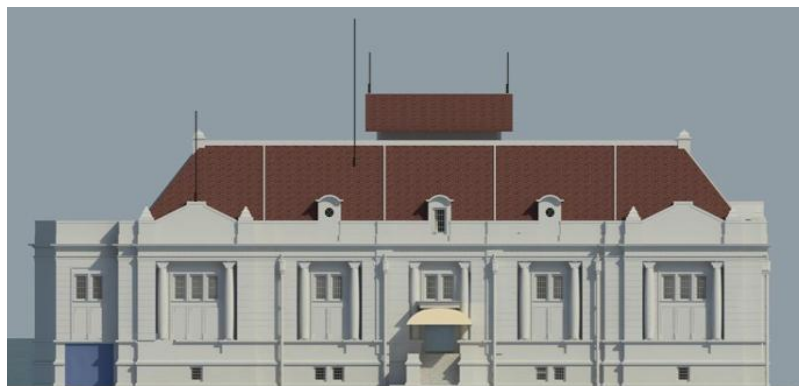

TAMPAK UTARA
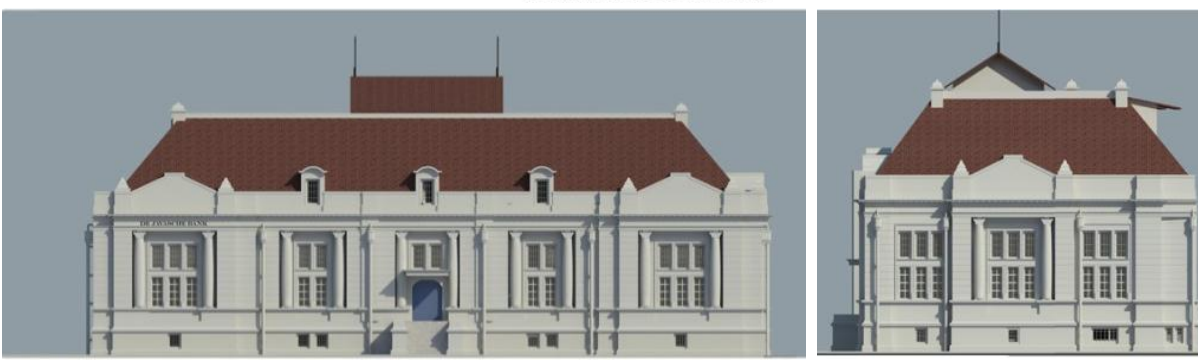

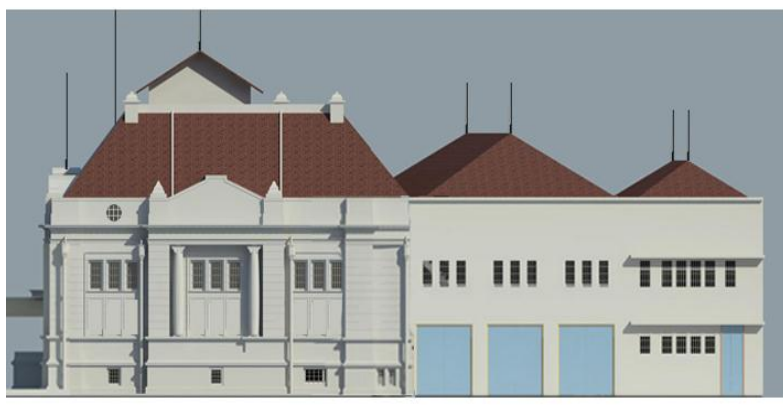

TAMPAK BARAT

Gambar 6. Tampak Utara dan Barat tahun 2009 (atas) dan pedoman konservasi untuk Tampak Utara dan Barat (bawah)
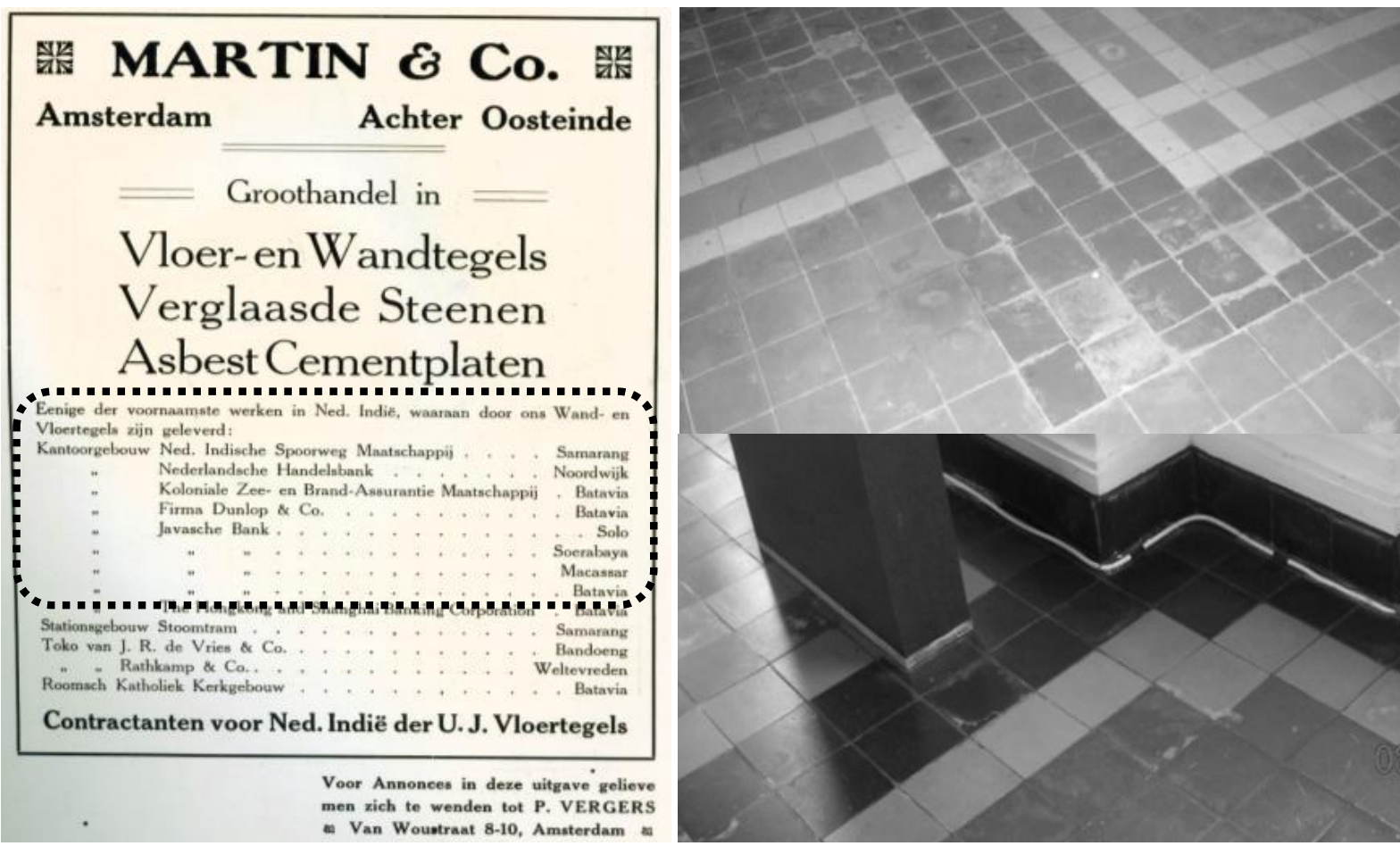

Gambar 7. Tegel lantai dari Amsterdam digunakan di beberapa Bank (kiri), dipergunakan di De Javasche Bank di Surabaya (kanan atas) dan di Jakarta (kanan bawah)

ukiran pada parapet, serta cornice dan dentil; (2) menghilangkan: (a) lubang angin tambahan dan tralis besi yang ada, (b) penutup papan triplek pada jendela; dan (3) mengembalikan tampak bangunan pada bentuk semula yaitu tanpa bangunan tambahan, lubang angin dan teralis besi.

Pada denah bangunan, pedoman konservasi adalah (Gambar 8): (1) mempertahankan: (a) tatanan ruang yang ada saat ini; (b) tanga ke lantai dasar, tangga dan pintu masuk putar; (c) bahan dan pola lantai yang ada; (2) menghilangkan: (a) lantai tambahan di sisi Selatan; (b) ruang direksi dan tangga; (c) tangga ke lantai tambahan di belakang; (d) tangga ke lantai 2 melalui lantai tambahan di belakang; (3) mengembalikan: kondisi lantai ke bentuk dan pola semula dengan tegel baru yang relatif sama (Gambar 
7 dan 8). Berdasarkan dokumen iklan Martin \& Co. Amsterdam dan analisis tipologi tegel lantai antara De Javasche Bank Surabaya dengan De Javasche Bank
Jakarta, dapat disimpulkan bahwa tegel lantai De Javasche Bank Surabaya adalah tegel yang asli (Gambar 7).
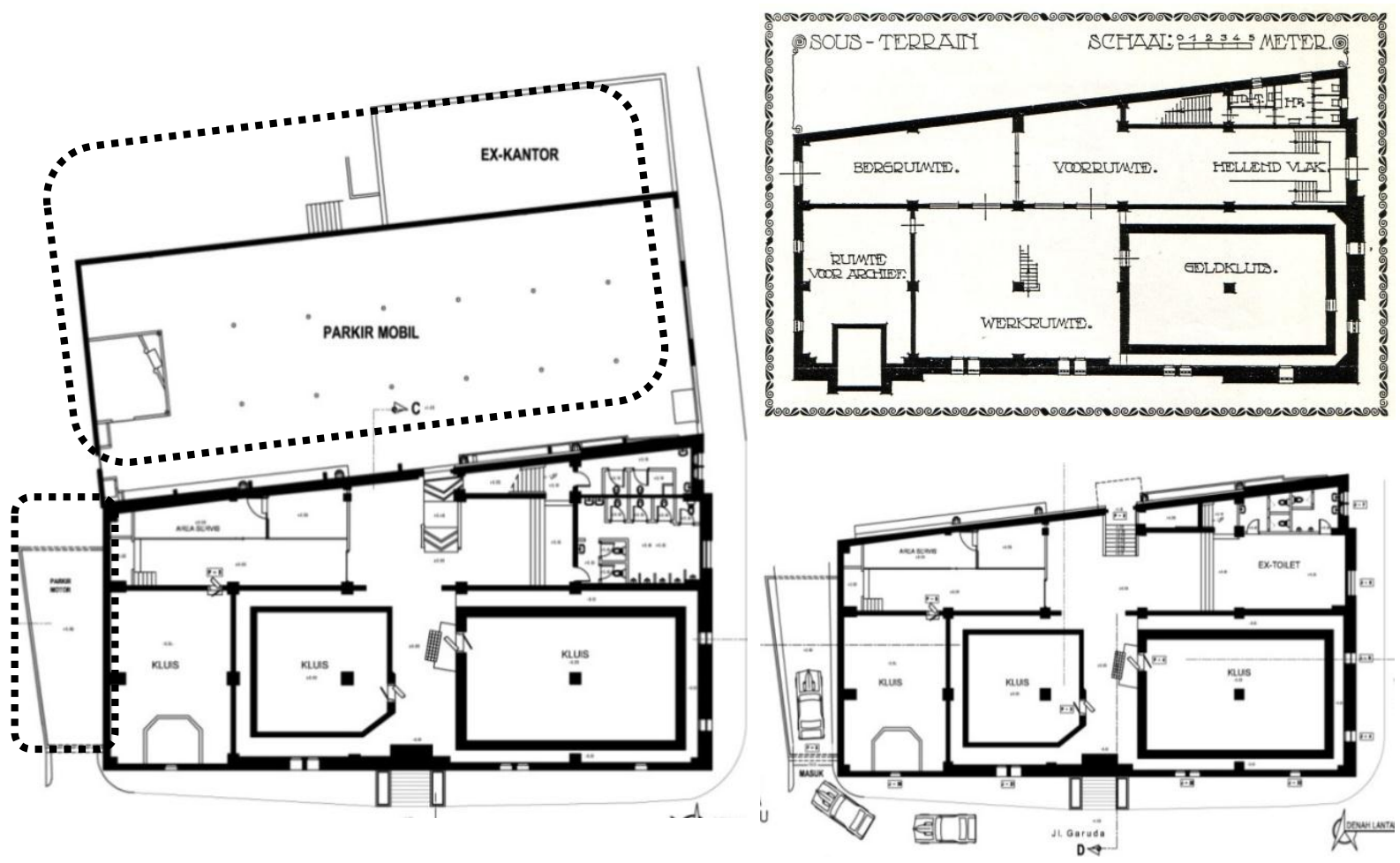

Gambar 8. Denah bangunan saat ini (kiri), denah asli tahun1910 (kanan atas), dan pedoman konservasi untuk denah (kanan bawah).
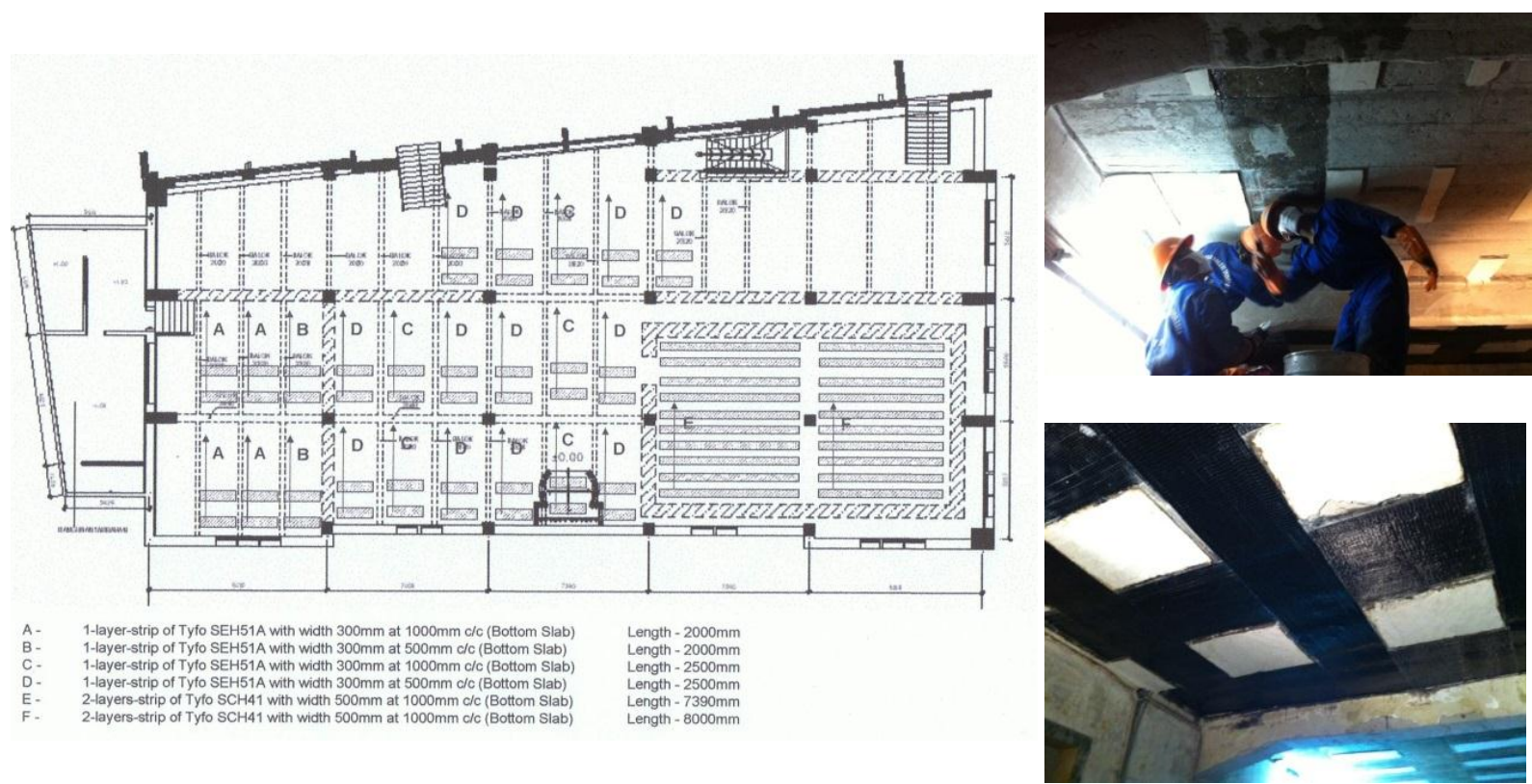

Gambar 9. Pedoman perkuatan balok dan kolom menggunakan Fiberwrap Systems (kiri), dan pelaksanaan pemasangan fiberwrap pada plat lantai (kanan) 


\section{B. Pedoman Perkuatan Struktur}

Berdasarkan hasil analisa kekuatan struktur dengan program ETABS, maka perlu tindakan perkuatan struktur. ${ }^{4}$ Untuk dinding, tegangan tekan terbesar masih dalam batas toleransi yang dapat diterima oleh dinding bata pemikul untuk dapat menahan beban rencana yang mungkin terjadi, sehingga untuk menahan beban gravitasi tidak diperlukan tindakan perkuatan. Namun untuk balok menunjukkan tulangan lentur yang sangat sedikit, hanya ada dua tulangan yang terpasang, maka perlu tindakan perkuatan. Untuk kolom, jumlah tulangan yang ada pada tiap kolom sekitar 8-12 tulangan dengan jarak sengkang antara 200-400 mm yang belum dapat menahan beban rencana dengan aman, maka perlu tindakan perkuatan kolom. Perkuatan balok dan kolom tidak dengan menambahkan besi baja dan penebalan, tetapi dengan metode perbaikan menggunakan Fiberwrap Systems yang tidak akan mengubah bentuk struktur bangunan, tetapi hanya membungkus atau melapisi permukaan struktur (Gambar 9).

\section{Tahapan Intervensi}

Pembahasan sebelum di atas sudah menunjukan terjadi kerusakan struktural dan tindakan perkuatan struktur. Untuk kerusakan yang bersifat komponen pada sebagian elemen-elemen bangunan, maka secara teknis tahap pekerjaan konservasi yang diperlukan adalah: (1) pembongkaran, (2) pembersihan dan pengelupasan, (3) pengawetan, (4) perbaikan dan perkuatan yang meliputi: penyambungan bahan sebagai tindak lanjut amputasi (bonding); mengisi celah-celah kerusakan (filling); perkuatan bahan (konsolidasi); injeksi; replacing; kamuflase, (5) perlindungan (coating), dan (6) dokumentasi setiap proses tahapan.

\section{Menggali Data yang Belum Terungkap}

Dalam pelaksanaan pekerjaan konservasi terlebih dahulu harus dilakukan studi arkeologis untuk mencari data kondisi asli bangunan yang belum terungkap, misalnya bekas pintu masuk ke lantai dasar, warna cat dan pelitur, komposisi material

\footnotetext{
${ }^{4}$ Untuk analisa kekuatan struktur, rencana beban mati adalah berat sendiri bangunan ditambah beban hidup berupa air hujan, barang yang mudah bergerak, dan beban pengunjung. Beban hidup untuk lantai 1 diasumsikan sebesar $500 \mathrm{~kg} / \mathrm{m} 2$ dan untuk lantai 2 yang jarang diakses diasumsikan sebesar $250 \mathrm{~kg} / \mathrm{m} 2$ sesai dengan Peraturan Pembebanan Indonesia.
}

lapisan plester, bentuk-bentuk ornament kolom dan dinding, dan nama De Javasche Bank pada dinding luar (Gambar 10). Temuan-temuan data yang belum terungkap ini dapat dilakukan dengan metode ilmu purbakala yaitu melalui ekskavasi, pembongkaran, dan pengelupasan untuk mencari lapisan warna cat atau benda yang terpendam atau tertutup oleh elemen lainnya. Untuk memenuhi prinsip 'material authenticity' dalam konservasi, maka harus dilakukan uji laboratorium untuk mengatahui komponen dan komposisi setiap bahan bangunan yang akan diperbaiki atau diganti. Sebagai contoh adalah hasil uji laboratorium di Balai Konservasi Peninggalan Borobudur untuk mengetahui komposisi material lapisan plester pada beberapa sampel plester pada dinding lantai dasar (Gambar 11).

Berdasarkan hasil uji laboratorium ini, maka temuan komposisi material asli yang akan dipergunakan pada konservasi bangunan adalah 2 pasir: 1 bata merah: 1 kapur (sampel plester A), komposisi ini merupakan material "dinding bernafas" yang merupakan bahan plester yang umum dipergunakan sebelum semen dipergunakan. Sesuai dengan perkiraan semula, sampel plester B dan C memiliki komposisi plester dengan semen karena plester B adalah pada kluis yang merupakan elemen tambahan, sedangkan plester $\mathrm{C}$ kemungkinan telah mengalami beberapa kali perbaikan dengan bahan plester baru

\section{E. Pedoman Desain Elemen Baru}

Sesuai dengan prinsip 'recognizable as a new', maka untuk elemen-elemen baru seperti pintu masuk sisi selatan bangunan (pintu belakang), tangga ke lantai 2, jaringan listrik, utilitas bangunan (AC, jaraingan air bersih, sprinkler, pemadam kebakaran) mempergunakan bahan dan teknologi baru untuk dapat dibedakan dengan elemen yang lama sebagai representasi masa saat ini (Gambar 12). Selain itu, sesuai dengan prinsip intervensi minimum, elemenelemen baru ini hanya ditempelkan saja dengan elemen pengikat pada elemen dinding dan lantai, agar sedikit mungkin merusak elemen asli pada bangunan.

\section{KESIMPULAN}

Manage change atau mengelola perubahan menjadi kata kunci dalam perencanaan konservasi bangunan ini. Dalam perjalanan waktu, bangunan De Javasche Bank Surabaya telah mengalami beberapa perubahan sejak dibangun tahun 1910 sampai pada kondisi saat ini, baik pengurangan elemen asli maupun penambahan elemen baru pada gedung. 

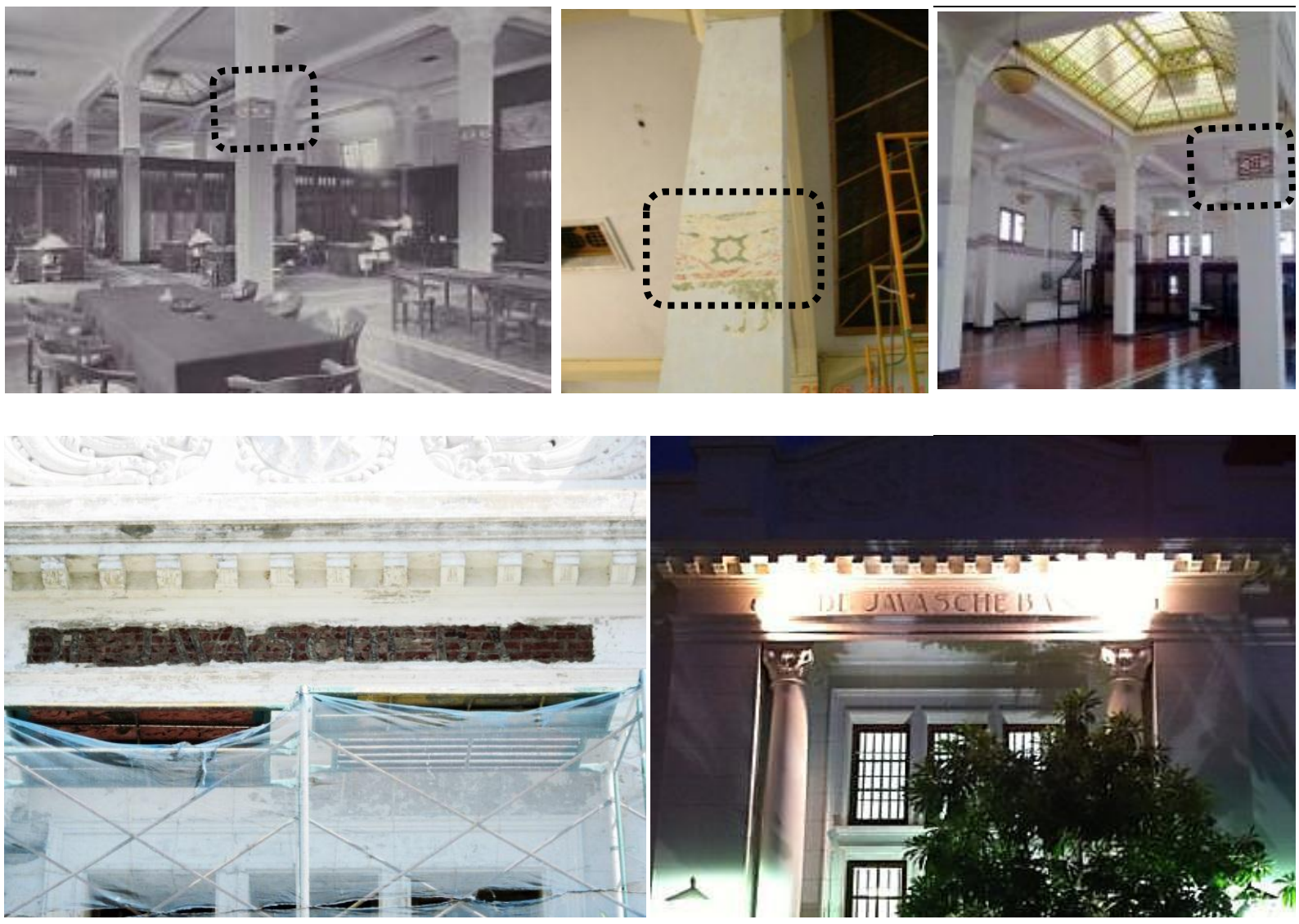

Gambar 10. Ornamen kolom sesuai kondisi bangunan tahun 1910 (kiri atas), hasil eskavasi pada kolom yang menemukan ornamen yang hilang (kiri atas tengah), hasil konservasi pada kolom (kanan atas), eskavasi nama De Javasche Bank (kiri bawah), dan hasil konservasi nama De Javasche Bank (kanan bawah). Sumber: bangunan tahun 1910, KITLV

Untuk itu, perencanaan konservasi gedung ini disusun untuk mengelola perubahan yang terjadi dengan tetap memenuhi prinsip utama dalam konservasi yaitu authenticity, melalui intervensi-intervensi yang dilakukan, seperti (1) pelestarian atau mempertahankan semua elemen-elemen asli bangunan tahun 1910 dan sebagian elemen-elemen bangunan kondisi eksisting (exiting state) seperti pintu masuk utama; (2) rehabilitasi, restorsi, dan rekonstruksi elemen-elemen bangunan yang telah hilang dan rusak; (3) demolisi elemen-elemen baru atau tambahan yang mengganggu dan menutupi elemen asli tahun 1910, (4) dalam hal penambahan elemen-elemen baru karena kebutuhan tuntutan kenyamanan dan keselamatan bangunan seperti sistim MEP (jaringan listrik, sistim $\mathrm{AC}$, kebakaran, air bersih), prinsip intervensi minimum dapat dipenuhi dengan cara seminim mungkin merusak lantai dan dinding yang ada dengan memanfaatkan lubang-lubang yang ada; dan (5) penambahan elemen-elemen arsitektur yang baru seperti tangga dan pintu masuk sisi selatan dengan material baru untuk membedakan dengan material yang asli sebagai representasi masa kini, sesuai prinsip 'discernable' dalam konservasi.

\section{Ucapan Terima Kasih:}

Saya ucapkan terima kasih kepada Ir. Handinoto, MT. dan Antoni, $\mathrm{PhD}$ yang ikut membantu dalam menyusun studi sejarah dan struktur bangunan ini.

\section{DAFTAR PUSTAKA}

Achmad, Y. (2006) "The Scope and Definitions of Heritage: From Tangible to Intangible", International Journal of Heritage Studies 12, 292-300.

Akihary, H. (1990) Architectuur \& Stedebouw in Indonesië, Zutphen, De Walburg Pers.

Bank Indonesia (2008) Konservasi Gedung Bank Indonesia Kota Jakarta, Jakarta, Direktorat Logistik dan Pengamaan BI.

Chu, C. (2007) "Heritage of disappearance? Shekkipmei and collective memory(s) in post-handover Hongkong", Traditional Dwellings and Settlements Review, XIII, 4355.

Dick, H.W. (2003) Surabaya, City of Work: A Socioeconomy History, 1900-2000, Singapore, Singapore University Press, National University of Singapre. 

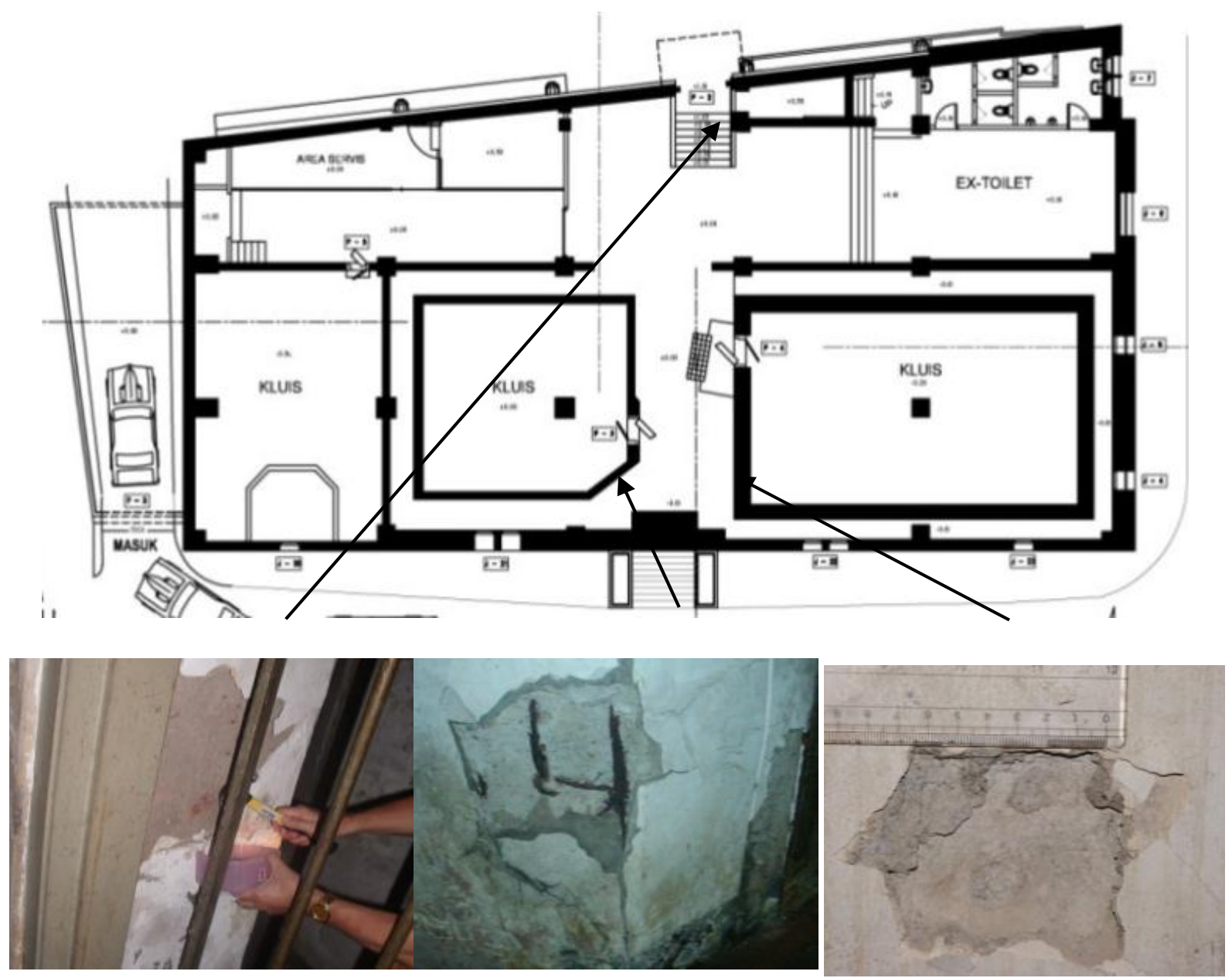

HASIL ANALISIS LABORATORIUM BALAI KONSERVASI PENINGGALAN BOROBUDUR

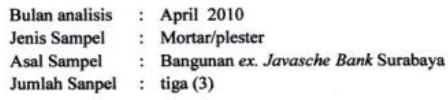

I. Pendahuluan

Sampel yang diuji merupakan sampel plester. Parameter yang diuji untuk sampel plester meliputi analisis fisik dan kimia untuk mencari komposisi dari plester.

II. Data Analisis

A. Data analisis komposisi bahan

\begin{tabular}{|c|l|c|c|c|c|c|}
\hline \multirow{2}{*}{ No. } & \multirow{2}{*}{$\begin{array}{c}\text { Jenis } \\
\text { Sampel }\end{array}$} & \multirow{2}{*}{ Kode } & \multicolumn{3}{|c|}{ Komposisi } & \multirow{2}{*}{ Keterangan } \\
\cline { 4 - 6 } & & $\begin{array}{c}\text { Pasir } \\
(\%)\end{array}$ & $\begin{array}{c}\text { Debu } \\
(\%)\end{array}$ & $\begin{array}{c}\text { Kapur } \\
(\%)\end{array}$ & \\
\hline 1 & Plester & A & 71 & 7 & 22 & Terdapat butiran bata merah \\
\hline 2 & Plester & B & 60 & 18 & 22 & \\
\hline 3 & plester & C & 63 & 16 & 21 & \\
\hline
\end{tabular}

B. Data analisis kimia sampel plester
\begin{tabular}{|c|l|c|c|c|c|c|c|c|c|c|}
\hline \multirow{2}{*}{ No. } & \multirow{2}{*}{$\begin{array}{c}\text { Jenis } \\
\text { Sampel }\end{array}$} & \multirow{2}{*}{ Kode } & \multicolumn{7}{|c|}{ Parameter/Hasil dalam Persen (\%) } \\
\cline { 5 - 11 } & & Ca & Mg & Fe & Al & SO, & C & CO, & SiO $_{2}$ \\
\hline 1 & Plester & A & 5,878 & 8,427 & 3,574 & 4,144 & 12,296 & 0,175 & 9,273 & 35,19 \\
\hline 2 & Plester & B & 12,826 & 10,21 & 1,743 & 2,266 & 6,916 & 0,245 & 19,391 & 25,57 \\
\hline 3 & Plester & C & 13,093 & 10,494 & 0,156 & 3,777 & 6,455 & 0,21 & 16,923 & 41,67 \\
\hline
\end{tabular}

\section{Pèmbahasan}

Dari analisis yang dilakukan diketahui bahwa sampel plester A terdapat campuran butiran bata merah. Sedangkan plester B dan C tidak ditemukan campuran bata merah. Sampel A diperkirakan merupakan mortar tradisional tanpa campuran semen PC, hal tersebut dapat dilihat dari kekerasan sampel dan warna sampel. Sampel B dan C diperkirakan merupakan campuran antara pasir, kapur dan semen. Perkiraan komposisi untuk plester $A$ adalah terdiri dari pasir : bubuk bata merah : kapur dengan perbandingan $2: 1: 1$. Sedangkan plester B dan C diperkirakan merupakan campuran pasir : kapur : semen dengan perbandingan $3: 1: 1$.

Adanya kandungan semen $\mathrm{PC}$ dalam sampel $\mathrm{B}$ dan $\mathrm{C}$ juga dapat dilihat dari data analisis kimia dimana kandungan $\mathrm{Ca}, \mathrm{Mg}$, dan $\mathrm{CO}_{3}$ lebih besar bila dibandingkan dengan dengan sampel $\mathrm{A}$. sedangkan adanya campuran butiran bata merah dapat dilihat dari kandungan $\mathrm{Al}$ pada sampel $\mathrm{A}$ lebih besar dari B dan $\mathrm{C}$

Magelang, 28 April 2010 Kasi Pelayanan Teknis,

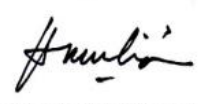

Iskandar M. Siregar, S.Si NIP. 19691118199903100

Gambar 11. Titik Pengambilan Sampel Plester di Lantai Dasar dan Hasil Uji Laboratorium untuk Komposisi Plester 

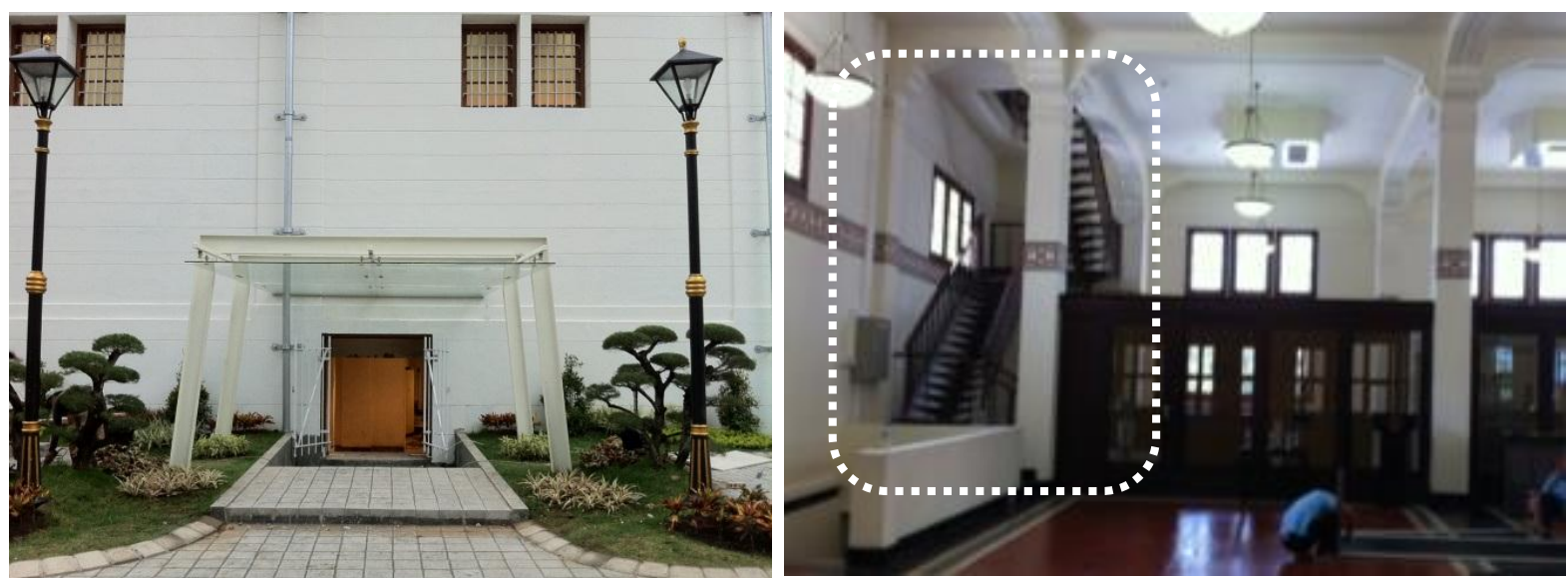

Gambar 12. Salah satu contoh elemen baru dengan material modern: pintu masuk Selatan dengan material baja dan kaca (kiri), tangga ke lantai 2 dengan bahan baja (kanan).

Emerick, K. (2001) "Use, Value and Significance in Heritage Management" in R. Layton et al eds. Destruction and conservation of cultural property pp. 276-285, London, Routledge.

Engelhardt, R. \& Unakul, M.H. eds. (2007) Asia Conserved: Lesson Learned from the UNESCO Asia-Pacific Heritage Awards for Cultural Heritage Conservation (2000-2004), Bangkok, UNESCO.

English Heritage (2008) Conservation Principles: Policies and Guidance for the Sustainable Management of the Historic Environment, London, English Heritage.

Faber, G.H. von (1931) Oud Soerabaia: De Geschiedenis Van Indie's Eerste Koopstad Van De Oudste Tijden Tot De Insteling Van De Gemeenteraad, Surabaia, Gemeente Surabaia.

Feilden, B. M. (2003) Conservation of Historic Buildings, Oxford, Architectural Press.

(1989) Conservation of Historic Buildings, Oxford, Architectural Press.

. (1982) Conservation of Historic Buildings, Oxford, Architectural Press.

Fermont-Cuypers (1937) "De Javasche Bank en Andere Kantoorgebouwen te Batavia", I,B.T. Locale Techniek 2, 50-55.

"Het Gebouw van De Javasche Bank de Soerabaia", Het Nederlandsch Indische Huis Oud en Nieuw 1913-14, 1\&2 jaargang, 81-86.

Heynen, H. (2006) "Questioning Authenticity", National Identity 8, 287-300.

ICOMOS-Australia 1999, The Burra Charter: the Australia ICOMOS Charter for Places of Cultural Significance, accessed 27 April 2007, available from http://www.australia.icomos.org.
Jokilehto, J. (2007) 'Conservation concepts' in Conservation of ruins", ed. J. Ashurt, Oxford Elsevier Limited.

Kwanda, T. et al (2010) Konservasi Gedung eks De Javasche Bank Surabaya: Sejarah, Dokumentasi, Pedoman Konservasi, ed. Handinoto, Jakarta, Direktorat Logistik dan Pengamaan BI.

Logan, W.S. eds. (2002) The Disappearing 'Asian' City: Protecting Asia's Urban Heritage in Globalizing World, New York, Oxford University Press.

Loulanski, T. (2006) "Revising the concept for cultural heritage: the argument for a functional approach", International Journal of Cultural Property 13, 207-233.

M. Vinas, S. (2005) Contemporary Theory of Conservation, Amsterdam, Elsevier-Butter WorthHeinemann.

Prudon, T. H. M. (2008) Preservation of Modern Architecture, Hoboken, John Wiley \& Sons.

Stanly P., Nicholas, Talley Jr., M. K., Alessandra. M. V. eds. (1996) Historical and Philosophical Issues in the Conservation of Cultural Heritage, Los Angelos, The Getty Conservation Institute.

The Athens Charter 1931, International Charter for Restoration of Historic Monuments, accessed 17 April 2009, available from http://www.international.icomos.org/e_athens.htm

The Venice Charter 1964, International Charter for the Conservation and Restoration of Мопиments and Sites, accessed 17 April 2009, available from http://www.international.icomos. org/e_venice.htm 